\title{
Study on Coffee Marketing and Farmer Organization in Pasuruan District
}

\author{
Lya Aklimawati ${ }^{1 *}$ \\ ${ }^{1)}$ Indonesian Coffee and Cocoa Research Institute, Jl. P.B. Sudirman 90 Jember 68118 \\ ${ }^{*}$ Corresponding author: lya.akli@gmail.com \\ Received: 25 January 2018/ Accepted: 17 April 2018
}

\begin{abstract}
Complexity of coffee supply chain system encourages business actors to optimize supply chain management as an effort to increase market transparency among them. Consolidating in farmer organization was required to strengthen bargaining position of farmer for facing the complexity of supply chain system. The aim of this research was to analyze supply chain and marketing margin on coffee marketing; and to analyze the characteristics of coffee farmer organization. This research was conducted in Pasuruan district as one of coffee producing area in East Java. Number of respondents were 18 that consisted of 16 farmers and 2 extension officers. The respondent was determined by snowball sampling method. The data was considered a primary data and secondary data was used as supporting data. Data were analyzed by using descriptive method and marketing margin analysis. The result showed that coffee marketing chain in Pasuruan district would lead to a relatively long and complex which was dominated by collectors. The highest profit of Arabica coffee marketing received by collectors was gained by selling green beans. On the Robusta coffee marketing, the highest profit was derived by selling fresh cherries. Farmer organizations could not be able to improve their bargaining position and market access as a result of weakness on the role and function of them.
\end{abstract}

Keywords: supply chain, farmer organization, coffee, oligopsony, marketing margin, Pasuruan

\section{INTRODUCTION}

Coffee is one of the plantation commodities with a quite complex market network. Such complexity is reflected in the relatively long marketing system and market power dominated by certain market participants only. According to Hasibuan et al. (2015), the domination of market participants, especially vendors, over the marketing system will lead to a situation where the supply chain performance cannot be managed optimally. This has something to do with the distribution of profits between suppliers and consumers in the marketing system.
Supply chains are system market participants which can be used in order to make profits from marketing coffee. Economic activities in a supply chain do not consist of distributing goods from producers to end consumers only, but they also include conveying information and cash flow from end consumers to suppliers, and vice versa (Mentzer et al., 2001; Widyarto, 2012; Hidayat et al., 2012). A supply chain will be efficient if each market link is familiar with dynamics in the flow of information as information is indicated as a key in the supply chain system (Lambert \& Cooper, 2000). Therefore, the flow of information and cash flow play an important role 
in strengthening the bargaining power of market participants. By gathering market information, market participants may have power to influence prices, thereby obtaining a relatively high margin. In general, market participants who often derive much benefit are vendors (Lokollo, 2012; Zunaidah et al., 2013). Meanwhile, suppliers or farmers cannot enjoy a profit margin from coffee trading because farmers have weaknesses, especially in negotiating prices with vendors.

Farmers limited power to negotiate prices results from farmer institutional arrangement that has not been implemented according to its roles and functions (Tollens, 2006; Nasrul, 2012; Rahman et al., 2014). Farmers have not used institutional arrangement as a forum for organizations to streng then their market position and develop coffee trading. Therefore, efforts should be made to change farmer mindset to run market-oriented farming. The existence of institutional arrangement is deemed vital for expanding farmers market networks and enhancing the efficiency of coffee marketing at the farmer level. In this condition, farmers need to play their role in optimizing supply chain performance. Farmers have a major role in improving product competitiveness and maintaining supply quantities. Organizing farmers in institutional arrangement will ensure sustainability of supply to customers.

To deal with competition in coffee trading, it is important to understand the supply chain concept. In principle, supply chains do not only consider logistics, but they also deal with purchase, manufacture, and distribution as well as end consumers. A supply chain system includes two flows, namely the flow of products from suppliers to end consumers, and the flow of information from end consumers to suppliers. Thus, supply chains do not control production or distribution of products only, but they also control networks in order that consumer demands can be met in no time (Winarto, 2006; Hadiguna \& Putra, 2015).

To classify whether a supply chain system is a complex one or a simple one depends on the number of market participants involved in the system. The higher the number of market participants involved is, the less transparent the market information is. This results from a conflict of interests among market participants. Such a condition results in small value-added obtained by farmers as the provider of raw materials. In the supply chain concept, market participants are expected to enjoy added value proportionally (Said, 2006; Hadiguna \& Putra, 2015). In reality, only certain high added value potential is only enjoyed by certain market participants, especially vendors, who enjoy the potential for high value-added. This indicates that farmer organizations remain unable to encourage their member farmers to strengthen the bargaining position in the marketing system. The existence of organizations and the role of farmers in encouraging organizations are crucial to enhance farmers bargaining position. In this research, the supply chain to be examined was limited to the trade of coffee, especially the primary products. The analysis of the characteristics of farmer organizations focused on farmer empowerment through interactions or cooperation among group members.

Based on the foregoing, supply chain performance and the existence of organizations at the farmer level are critical to strengthening farmers access to markets. From a social point of view, farmer organizations are considered important to strengthen the bonding and social interactions among member farmers. This research aimed to analyze the supply chain and marketing margin in coffee trade; and to examine the characteristics of coffee farmer organizations. 


\section{MATERIALS AND METHODS}

This research was undertaken in Pasuruan district in July 2016. The research sites included five sub-districts, namely Prigen sub-district, Tutur sub-district, Purwodadi sub-district, Purwosari sub-district, and Puspo sub-district. Those research sites were chosen deliberately considering that those five sub-districts were the largest coffee producers in Pasuruan district. Moreover, another consideration, there are farmers who actively participate in the activities of farmer groups and farmers who switch to growing elephant grass and chrysanthemums.

The primary type of research data used was primary data with secondary data as supporting data in answering research objectives. The data were collected by conducting a survey as the data collection method through direct observation and interviews with some respondents that had been selected. Observation was carried out by observing and recording systematically the research topic under study. Interviews were conducted using a list of questions to gain information and primary data, including post-harvest handling, marketing channels, types of coffee products sold, prices, processing costs, farmer group characteristics, and farmer group activities. Secondary data were gathered by collecting data related to the research findings. Secondary data derived from a collection of research findings relevant to the research topic and statistical data from relevant agencies.

This descriptive research aimed at describing and explaining the conditions or phenomena that take place amidst society in accordance with the topic under study. This research does not require a wide sample of respondents. The assumption used is that respondents are informants who are considered to know about the phenomena under study (Rianse \& Abdi, 2009). Thus, the respondents were chosen using a non-probability sampling approach with the method of snowball sampling (Kendall et al., 2008; Noy, 2008). The use of this method aimed to discover initial information about the research population (Cohen \& Arieli, 2011) and the social conditions of the community, as well as to assist in selection of the respondents (Handcock \& Gile, 2011). In this research, selection of the respondents did not emphasize the number of respondents, but it focused on the information the respondents had. There were a total of 18 respondents, consisting of 16 vendor farmers and 2 extension workers.

Research data were analyzed using a descriptive method and based on the marketing margin. A descriptive analysis (Kipdiyah et al., 2013) was used to systematically interpret qualitative data in the form of descriptions, symbols or reports related to the coffee supply chain. The marketing margin analysis was used to determine the difference between the price paid by consumers and the price received by farmers. The following are mathematical equations for calculating the marketing margins (Anggraini et al., 2013; Widiastuti \& Harisudin, 2013; Gachena \& Kebebew, 2014):

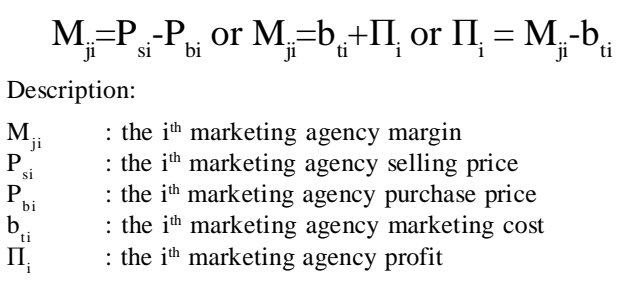

\section{RESULTS AND DISCUSSION}

\section{Coffee Marketing Chain}

Results of the survey at the research sites revealed that the marketing chain consisted of several marketing channels. Marketing agencies involved in the coffee supply chain system were farmers, collectors, wholesalers, exporters, and processing industries/coffee 
shops. The market links in Pasuruan district were limited to farmers, collectors, and coffeeprocessing home industries. While other links such as wholesalers, exporters, and coffee shops are located in other areas, especially Malang and Jember. In this case, the distribution of coffee to market chains in different regions will cause the marketing channel in Pasuruan to be relatively long. According to ECX cit. Gachena \& Kebebew (2014), consequences that arise as a result of a long marketing chain include a high cost and a risk to trade transactions, as well as limited market information as there are a great number of market intermediaries.

To reach the market, farmers are classified into two criteria, namely subsistence farmers and commercial farmers. The first typically produce coffee in small quantities, thus their produce is sold to collectors nearby their hamlets, villages, sub-districts, or fellow farmers only. While the latter will market their products directly to larger markets. It is known that the market access of subsistence farmers is different from that of commercial farmers. Based on this case, it is indicated that the amount of profit a marketing agency makes will depend on access to a larger market. Farmers who approach the market with a high level of demand will get benefit, especially in terms of prices. This condition is consistent with findings of the research by Godfrey \& Agnes (2012) into potato marketing in Rungwe District, Tanzania.

\section{Coffee Market Structure}

The coffee market in Pasuruan district has been divided into the primary product market and the secondary product market. This research focus more on the mechanism and structure of primary products, rather than those of secondary products. The market chain presented in Figure 1 shows that there are several links that serve as intermediaries that connect farmers with exporters. The structure of the coffee market for primary products in Pasuruan district tends to resemble that of the oligopsony market. Similarly, in the market of downstream coffee products, there are some buyers who supply processed coffee from farmers or collectors. There are two marketing channels for the sales of downstream coffee products until the products approach consumers. Farmers undertake downstream processing on their own and market the product directly to end consumers. In addition, farmers get coffee-processing home industries to process coffee and later sell it to end consumers. Through this downstream processing activity, farmers can obtain value-added from their coffee products.

\section{Marketing Institutions}

Farmers: Each marketing agency has its own role in influencing the supply chain performance. Farmers have a major role in producing various types of coffee products, especially fresh coffee cherries, dried coffee cherries, and coffee beans. The types of coffee products sold depend on what each farmer wants and needs. Most farmers store and market coffee in form of dried coffee cherries as a result of lack of processing facilities among farmers or farmer groups, in addition to marketing coffee individually. Nevertheless, there are also farmers prefer selling coffee beans as they are considered more profitable than selling them in form of dried cherries. Such an interest is also supported by the availability of processing facilities, especially the huller machine. Quality of coffee is determined by the processing at the farmer level. Individual marketing will result in farmers weak bargaining position and vendors domination in determining prices. As the provider of raw materials, farmers have joined farmers groups but the role of these farmer groups in the supply chain system has not been 
performed properly. Farmer groups have not served as an intermediary or a marketing agency for their member farmers. Therefore, organization of farmers in the procurement of supply and collective marketing remains unable to be implemented. Farmer groups remain unable to assist their member farmers in undertaking processing and marketing in groups. However, several farmer groups have received assistance in form of processing facilities from the government. On the other hand, there is a conflict of interests between farmer organizations, which is the farmer group administrators also serves as a collector. This will cause the information in the supply chain system to be less transparent.

Collectors: Collectors in the research sites are classified into hamlet-level collectors, village-level collectors, sub-district-level collectors, and middlemen from Dampit Subdistrict, Malang Regency. Those collectors greatly dominate determination of prices at the farmer level, as they are the marketing agency closest to the farmers. The proximity of collectors to farmers has resulted in a condition of farmers dependence, meaning that farmers consider that market access to collectors is easier way than accessing other larger markets. Realities show that the majority of farmers lack access to information and market networks. Such a condition forces them to market coffee to middlemen or collectors only. Farmers cannot access other market networks that offer higher prices. These collectors generally play a dual role, namely as collectors and farmers.

Wholesalers: Survey results indicate that wholesalers dominating coffee trade in Pasuruan district come from Dampit subdistrict, Malang district. But for the Arabica coffee market, collectors usually supply to wholesalers in Jember district. In addition to supply from collectors, wholesalers usually buy coffee from farmers through their own market network or middlemen who come meeting the farmers during the harvest season. This information indicates that the operational area of wholesalers is relatively large because they do not only get supply from local collectors, but also have their own market network. This aims to meet the supply needs of exporters/processing industries. These wholesalers certainly have a wider market network and a stronger bargaining position in terms of pricing. In relation to pricing, wholesalers and collectors will enter into a negotiation to agree on the price, supply quantity, and quality requirement. The role of wholesalers in the supply chain system does not only focuses on the purchasing and distribution capacity, but also on network arrangement, in this case collectors, to obtain the supply of coffee from farmers. Network arrangement is vitally necessary because collectors do not only supply coffee to wholesalers, but also market their coffee to other buyers.

Exporters: Similar to wholesalers, exporters are marketing agencies with the strongest bargaining position because of their vast market access and market information access. Exporters who have entered the coffee market in Pasuruan district are PT. Asal Jaya (Dampit, Malang) and PT. Indokom Citra Persada (Sidoarjo). These exporters collect coffee from farmers through both local vendors and market networks they have established themselves. Based on the information from farmers, the majority of coffee is supplied to wholesalers or exporters in Dampit, Malang. The emergence of competition among exporters to obtain the supply of coffee from farmers encourages them to manage the supply chain well starting from setting the purchasing capacity, distribution channels, production processes, and market networks.

Processing Industries: The processing industries in the coffee supply chain in the research sites comprised mainly of home 
industries. In addition, there are also farmers who supply coffee to coffee shops. The business of coffee-processing home industries is run by farmers who also act as administrators of a farmer group and a vendor. This makes the supply chain system for coffee become more complex because these farmers have a particular interest to run their business. This conflict of interests has something to do primarily with the determination of the purchase price of coffee at the farmer level. In this supply chain system, the coffeeprocessing home industries are the marketing agency obtaining the highest value-added as they carry out processing activities by processing raw materials (coffee beans) into processed coffee products (roasted coffee and coffee powder).

\section{Products and Information Flow}

In the marketing chain, there will be an exchange of information and product transactions between market links. Based on the flow of products, farmers supply coffee to collectors at hamlet, village, and sub-district levels, and middlemen or wholesalers from Dampit sub-district, Malang. Those vendors meet the farmers directly to purchase coffee. Research findings suggest that most farmers sell coffee in form of primary products, indicating that they still do not care about the value-added that can be created from this commodity. Vendors buy coffee from farmers in various forms of products such as fresh coffee cherries, dried coffee cherries, and coffee beans. Some vendors buy coffee based on a scheme locally known as sistem tebasan or sistem ijon (which is the act of buying produce before it is harvested). Farmers sell their produce using such systems in order to meet their needs. Thus, these farmers market network access lies only on the collectors. Unlike subsistence farmers, commercial farmers generally sell coffee beans to collectors at the sub-district level in Pasuruan or wholesalers from Dampit, Malang. These commercial farmers carry out further processing both drying and sorting out their coffee beans before selling them to the subsequent buyers. In addition to coffee beans, commercial farmers usually produce roasted coffee and coffee powder as well to be supplied to coffee shops and marketed to end consumers.

Collectors, middlemen, and wholesalers collect coffee that has been harvested in various forms such as fresh coffee cherries, dried coffee cherries, and coffee beans. Collector at the hamlet level then resell the coffee to collectors at village and sub-district levels. These village-level collectors supply the coffee to the sub-district-level collectors. Then, the supply of coffee from the subdistrict-level collectors will be distributed to wholesalers in Jember district or those in Malang district. Coffee is also distributed by collectors at the sub-district level directly to exporters in Malang district, Sidoarjo, or Surabaya. Collectors and wholesalers also carry out further processing and distribute coffee according to market demand. Coffee products may include rejected coffee beans, high-grade coffee beans, and processed coffee. Collectors does not only access the primary product market, but also expand their markets to the secondary product market. At this stage, the processing process undertaken is the downstream one that produces roasted coffee and coffee powder. Collectors who produce processed coffee are farmers who run business-oriented farming.

Especially for wholesalers from Dampit, Malang district, they purchase coffee directly from farmers and then supply it to exporters in the region. Collectors in Pasuruan and middlemen from Dampit, Malang district, constitute supply chain networks in the distribution of coffee to wholesalers or exporters in Malang district. Although further processing have been carried out by collectors and wholesalers, exporters remain running further 
processing as well to produce coffee according to market demand.

Based on the flow of products, coffee supply in Pasuruan district is still distributed and marketed by market participants from other regions. Such dependence on markets in other regions leads to the introduction of coffee products from Pasuruan to the markets, in the sense that the popularity of coffee from Pasuruan will grow through the market in other regions. Among the strategy to bring Pasuruan coffee closer to a wider market share is to attract buyers or exporters to enter the local market, enabling farmers to sell their products directly to exporters and other buyers in the area from where the coffee come. In relation to product quality, the existing marketing chain has not provided and marketed quality coffee. Therefore, farmers in Pasuruan district remain unable to enjoy the price premium from quality coffee products.

Based on the flow of information, the communication established between market links aims to distribute information about developments in the price, processing method, and product quality expected by consumers. The flow of information about price developments in this coffee supply chain system starts from exporters as exporters have broad access to market information. In addition to accessing developments in the coffee price in the international market, exporters deliver price information to their market chain networks by considering the price agreed with importers. The agreed price will be used as the standard price while negotiating even determining the purchase price of coffee until the farmer level. Information about prices will be informed to wholesalers and is later forwarded to collectors whom are their market networks. The flow of price information in the research sites shows that farmers are the last to receive such information. The existence of a great number of links involved in the supply chain system causes the delivery of market information to the farmer level become less transparent and incomplete. Such a condition is known as asymmetric information (Tollens, 2006; Lokollo, 2012) in the coffee supply chain system. The emergence of this condition will result in a situation where benefit is derived by certain marketing agencies only. In this case, some of the benefit derived from the supply chain is distributed to collectors because their role dominates the local market in Pasuruan district. Effective use of market information is highly necessary to increase shareholder value (Doyle, 2009) in the supply chain in order that profit sharing can be distributed to a range of marketing agencies involved. In this case, the term shareholder value is defined as the proportion of cash flow distributed in each market link.

In terms of information about processing methods and product quality, farmers receive such information from general consumers or coffee shops. These farmers are commercial farmers or collectors who process coffee according to the method of processing buyers expect. Coffee is sold to those buyers in the form of coffee beans. Commercial farmers or collectors carry out processing as requested by their consumer in order to increase the purchase price of coffee beans. In general, the purchase of coffee like this offers a higher price than the market price, but the volume of purchases is in small quantities. The marketing of coffee undertaken by both marketing agencies typically target a particular target market, which is a specific market or coffee shops. By accessing this specific market, information about prices and product quality can be received more quickly by farmers. The flowchart of products and information in the coffee supply chain system in Pasuruan Regency is presented in Figure 1. 


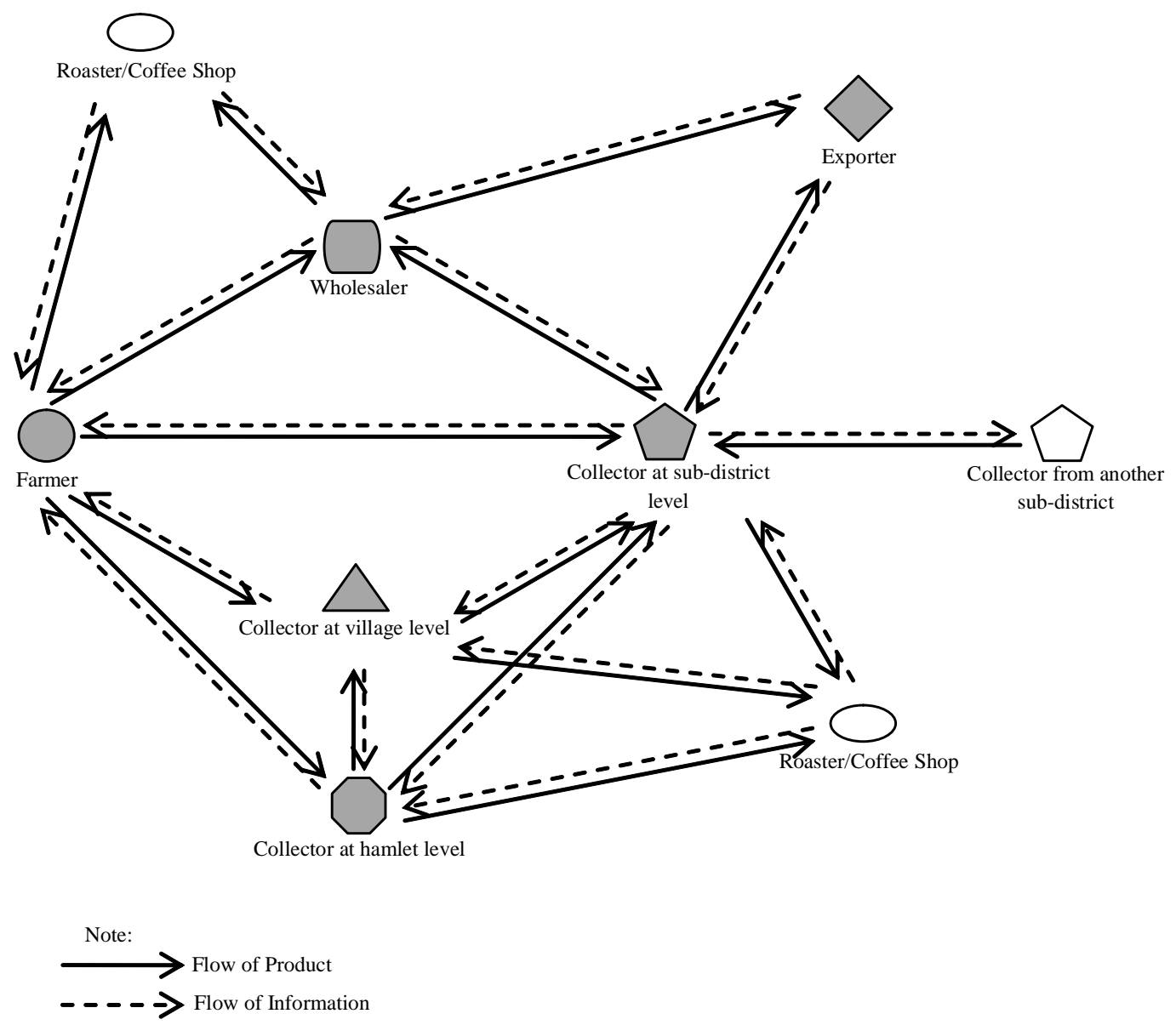

Figure 1. Coffee marketing channels in Pasuruan District

It can be said that the supply chain system found in the research sites is simple but complex. The system is deemed simple because decision making related to coffee marketing depends on the desire and needs of the farmers themselves. Farmers are still marketing their coffee products individually, enabling the decision to market coffee to be taken more quickly without the need for negotiation with others. On the other hand, the supply chain system is considered complex in terms of its marketing chain. The long coffee marketing chain in Pasuruan shows that the level of complexity of the supply chain system is quite high because there are quite a lot of marketing agencies involved, not to mention the conflict of interests between certain marketing agencies, especially farmers who also at the same time act as vendors. Besides acting as a vendor, those farmers also act as a group administrator In such a condition, farmers have a dual role making a conflict of interests related motives to seek the highest possible profits is unavoidable. As a group administrator, farmers need to encourage development among his/her member farmers and attempt to help his/her member farmers to get a reasonable price in the coffee marketing system. But as a vendor, farmers will tend to aim 
for maximum profits. With the overlapping role of a particular marketing agency, the coffee supply chain cannot function effectively. Therefore, collaboration between market links is required in order to realize an efficient supply chain. Through such collaboration, information about changes in consumer demand for coffee products will be informed to each market link. As stated by Cao \& Zhang (2012), collaboration between supply chains will benefit the market participants involved therein. This collaboration has been mediated by local governments through the establishment of Association of Coffee Farmers of Pasuruan district intended to establish communication and cooperation and exchange market information between farmers. However, the the establishment of the association still has not made any significant impact on improvements to supply chain and marketing performance.

\section{Margin at Collectors Level}

The structure of the coffee market in Pasuruan district tends to resemble that of the oligopsony market as marked by the existence of several major buyers. This market structure puts farmers in a weak position during price negotiation with collectors. Based on the survey results, there are quite many collectors in the research sites, making profits earned by vendors depend on the ability of the vendors to reduce marketing costs from farmers to buyers. The higher the cost of marketing to have products delivered to the next buyer is, the smaller the profits vendors make. Collectors sell not only fresh coffee cherries but also dried coffee cherries and coffee beans to buyers.

Results of the marketing margin analysis suggest that the marketing margins at the level of collectors for the sales of several Arabica coffee products amount to Rp3,500/ $\mathrm{kg}$ for coffee beans; Rp3,000/kg for dried coffee cherries; and Rp983.33/kg for fresh coffee cherries. Meanwhile, the marketing margins for Robusta coffee obtained by collectors amount to Rp1,500/kg for coffee beans; Rp500/kg for dried coffee cherries; and $\mathrm{Rp} 2,252.63 / \mathrm{kg}$ for fresh coffee cherries. The highest gross margin is obtained by collectors if they sell Arabica coffee in the form of coffee beans. Collectors will earn a relatively low gross margin if selling Robusta coffee in the form of dried coffee cherries. This is because collectors buy coffee from farmers in the form of dried coffee cherries and the collectors do not carry out any processing activity to market the coffee to the next buyer. In this case, collectors only get a differential from the purchase price from the farmers.

The marketing costs incurred by each vendors differ from each other. The components of the marketing costs are the costs of transport, sorting, drying, packaging, and loading and unloading. The percentage of marketing costs for Arabica coffee is generally lower than that of Robusta coffee. In the marketing of coffee beans, the marketing costs for Arabica coffee is equal to $10.71 \%$ of the gross margin and this value is greater than the marketing costs for Robusta coffee, which are $5 \%$. Collectors must incur the cost of transport for marketing the Arabica coffee they buy as the Arabica coffee market lies outside the region of Pasuruan district. To market Robusta coffee, the cost of transport is borne by buyers. Because, Robusta coffee market behavior in Pasuruan shows that it is the market networks of wholesalers and exporters that come to meet collectors to conduct transactions. In other words, the sale and purchase transaction is carried out at a collector's house. For the product of dried coffee cherries, the marketing costs amount to $0.48 \%$ and $5.26 \%$ for Arabica coffee and Robusta coffee, respectively, because vendors pay the packaging cost only. For the product 
of fresh coffee cherries, the percentage of the marketing costs is higher than those of coffee beans and dried coffee cherries. The marketing costs for Arabica coffee amount to $26.78 \%$, while marketing costs for Robusta coffee amount to $32.36 \%$ of the gross margin. High marketing costs for Robusta coffee are possibly because collectors incur the risk of storage, making them tend to carry out the drying process before fresh coffee cherries are sold completely. Collectors will shift their marketing to dried coffee cherries in the event that the supplies of fresh coffee cherries have not been sold completely.

The profits collectors generate from marketing Arabica coffee amount to Rp3,125/ $\mathrm{kg}$ for coffee beans; $\mathrm{Rp} 2,985.71 / \mathrm{kg}$ for dried coffee cherries; and Rp720/kg for fresh coffee cherries. The profits collectors generate from marketing Robusta coffee amount to $\mathrm{Rp} 1,425 / \mathrm{kg}$ for coffee beans; Rp473.68/kg for dried coffee cherries; and Rp1,523.68/ $\mathrm{kg}$ for fresh coffee cherries. Unlike the marketing of Arabica coffee, profits generated by collectors from the marketing of Robusta coffee is in the form of fresh coffee cherries are higher. Based on these results, domination of the role of collectors in determination of coffee prices at the farmer level can be revealed. Collectors make profits from the differential between the purchase price and the selling price. Results of the marketing margin analysis and the profits coffee collectors make are shown in Table 1.

\section{Farmer Organizations Characteristics}

Administratively, farmer groups in Pasuruan district have been formed and registered as an organizational forum. These farmer organizations generally still have no Articles of Association/Bylaws, but already have a legal entity and have been registered in the Ministry of Law and Human Rights. The establishment of legal entities aims to obtain legal protection, supervision, facilities, and grants from the government for empowering those farmer groups in accordance with the Law No. 23 of 2014. Farmer groups have been registered as legal entities since 2016. Facilities from the government for farmer groups will be given three years after the issuance of stipulation of those farmer group of the farmer group organizations as a legal entity. In relation to characteristics of the organization, each farmer group that participated as respondents in the research sites has different characteristics. Organizational characteristics are defined with reference to the social structure parameters in the research by Barham \& Chitemi (2009).

\section{Group Maturity Level}

The level of maturity of these groups is associated with how long the farmer groups have been established. The farmer group in the research sites have long existed, i.e. for more than five years. However, these farmer groups still have not carried out their organizational

Table 1. Margin and profit for coffee marketing at the collector level

\begin{tabular}{|c|c|c|c|c|c|c|}
\hline \multirow{2}{*}{$\begin{array}{l}\text { Component } \\
(\mathrm{Rp} / \mathrm{kg})\end{array}$} & \multicolumn{3}{|c|}{ Arabica coffee } & \multicolumn{3}{|c|}{ Robusta coffee } \\
\hline & Coffee bean & $\begin{array}{c}\text { Dried coffee } \\
\text { cherries }\end{array}$ & $\begin{array}{c}\text { Fresh coffee } \\
\text { cherries }\end{array}$ & Coffee bean & $\begin{array}{c}\text { Dried coffee } \\
\text { cherries }\end{array}$ & $\begin{array}{c}\text { Fresh coffee } \\
\text { cherries }\end{array}$ \\
\hline Purchase Price & $23,500.00$ & $15,000.00$ & $4,516.67$ & $23,500.00$ & $11,000.00$ & $3,800.00$ \\
\hline Selling Price & $27,000.00$ & $18,000.00$ & $5,500.00$ & $25,000.00$ & $11,500.00$ & $6,052.63$ \\
\hline Gross Margin & $3,500.00$ & $3,000.00$ & 983.33 & $1,500.00$ & 500.00 & $2,252.63$ \\
\hline \multicolumn{7}{|l|}{ Costs: } \\
\hline Transport & 300.00 & 0.00 & 166.67 & 0.00 & 0.00 & 150.00 \\
\hline Sorting & 0.00 & 0.00 & 46.67 & 0.00 & 0.00 & 0.00 \\
\hline $\begin{array}{l}\text { Drying, packaging, and } \\
\text { loading and unloading }\end{array}$ & 75.00 & 14.29 & 50.00 & 75.00 & 26.32 & 578.95 \\
\hline Profit & $3,125.00$ & $2,985.71$ & 720.00 & $1,425.00$ & 473.68 & $1,523.68$ \\
\hline
\end{tabular}


functions, especially in terms of using group resources to make the most of opportunities arising from emerging markets. Farmer groups mindset has not been directed towards exploring commercial farming. This results from lack of knowledge between farmer groups of commercial farming management and group administration management. Limited access of farmers to training is one of the factors that causes such an issue. With the enthusiasm of local governments and farmers to develop coffee, local governments initiated the establishment of the association of coffee farmers of Pasuruan in 2016 with a view to bridging coordination and communication between coffee farmers from different sub-districts in Pasuruan in order that they can exchange information about coffee farming. However, this newly formed farmer organization remains unable to bridge farmers from different regions in establishing communication and cooperation to seize market opportunities. This may result from poor institutional arrangement of each farmer group in each region in carrying out their respective organizational roles and functions. Based on this condition, it is indicated that the existence of farmer organizations, both those that have long existed and those newly formed, remain having no experience in exploiting their institutional functions and resources to capture the market. Successful empowerment of these organizations depends on efforts made by group administrators in each region to build partnerships with buyers.

\section{Group Size}

The group size shows the number of members in one group. The number of group members will affect the decision-making process, intervention against members, and implementation of collective marketing. It does not mean that the smaller the size of a farmer group is, the easier the organization of group members is. It depends on the active participation of and agreement between the group members to realize the shared objective. Farmer groups in Pasuruan have approximately 25 to 40 member farmers and fall into the category of small-sized groups. Despite the size, not all members participate actively in group activities. According to group administrators, only about $60 \%$ of the group members participated actively in group activities. This condition indicates vulnerability of farmer groups as a forum for farmers to engage in organizational activities and maintaining communication. Participation of those members suggest that the initiatives and motivation of both the administrators and the members to run farmer groups as a social organization remain low. Despite participation of members in group activities that exceeds $50 \%$, the desire and interest of farmers to empower farmer groups into one of the business entities still cannot be seen obviously.

\section{Group Activity Level}

The activity level is described based on the activities undertaken by a farmer group that are intended to facilitate its members. The actual condition shows that farmer groups still have not function as a "medium" to carry out the activities of facilitating their members. Farmer group activities, especially those intended to improve marketing performance, have not been undertaken. Farmer groups still have no plan to improve common prosperity through the implementation of collective processing and marketing. The idea of producing and marketing processed coffee products is still limited to the level of group administrators. Ideas related to collective marketing and production of processed coffee have not been included into the farmer group routine activities so that those ideas have not been informed to its members. Processed coffee product production and marketing activities been run by the female farmer group Sri Rejeki. This farmer group 
began to explore the downstream coffee market by marketing coffee powder. The group business activities are aimed at empowering women roles while increasing household incomes. On the other hand, the interest of other farmer groups in capturing new market opportunities has not been clearly visible. Some of the group activities that have been undertaken by the respondents are presented in Table 2.

In attempts to empower groups, farmer groups have organized regular meetings. The organization of regular meetings differs between farmer groups, ranging from every two weeks once to every 2-3 months. Despite regular meetings, participation of the members to attend group meetings is only about $60 \%$. The attendance rate of these members can be directed to encourage farmers to carry out their business activities in groups. To encourage participation of its group members, the farmer group Ampel Sari Makmur 2 collects dues from its members to meet production-related needs, such as buying fertilizer. On the other hand, the female farmer group Sri Rejeki already accessed funding from a microfinance institution, which is Labagus Cooperative. Based on the information the researcher has obtained, farmers used fresh coffee fruits with the percentage of red fruits of at least $85 \%$ to repay the capital loan including the interest. Determination of the coffee price was adjusted to the selling price of coffee in the market. Capital loans are used to produce processed coffee products and for the maintenance of coffee crops. Capital loans from cooperatives are considered to offer a relatively lower rate of interest, which is $1.5 \%$ per month. Most farmer groups have not use capital loans offered by banking institutions by arguing that bank loan interest is quite high.

The function of farmer groups as a social and community organization has been carried out by farmers group Ampel Sari
Makmur 2 and Sri Rejeki, especially through the provision of plantation maintenance or harvesting facilities. Both farmer groups provide plantation maintenance or harvesting facilities based on the principle of mutual assistance. This program is held once a week in turn. The group activity can help lighten the burden of its member farmers, especially in terms of the production costs that consist of the costs of labor to take care of plantations and to harvest. In relation to technology dissemination, most farmers stated that they had never attended any training in how to cultivate, process, and and market their products. Lack of training/mentoring activities cause coffee production and its quality at the farmer level to be low and varied. Therefore, product commercialization remains one of the obstacles facing subsistence farmers. The dissemination of technology and information up to the farmer level is very important and can be done through mentoring/training activities.

Important information obtained in this research is that the level of group activities and the level of group maturity are strongly correlated. The fact that the organizations still have not functioned properly indicates that the level of group activities tends to be less intensive as well. Even, farmer groups as a source of information and innovation have not been realized optimally. Conversely, farmer groups capable of carrying out their roles and functions well can encourage all members to develop businesses and connect their groups to wider markets.

\section{“Gender” and Group Leadership}

The management of each farmer group has been established. But, the role of the administrators in empowering the group differs between groups. Based on the cultures that exist amidst the communities in the research sites, the role of men in running 
Table 2. Internal farmer group activities in Prigen, Tutur, Purwodadi, and Puspo Sub-districts

\begin{tabular}{|c|c|c|c|c|c|c|c|c|c|}
\hline \multirow[b]{2}{*}{$\begin{array}{l}\text { Farmer } \\
\text { group } \\
\text { activity }\end{array}$} & \multicolumn{9}{|c|}{ Farmer Group } \\
\hline & $\begin{array}{c}\text { Mulyo } \\
\text { Rejo }\end{array}$ & $\begin{array}{c}\text { Subur } \\
\text { Makmur } 3\end{array}$ & $\begin{array}{l}\text { Manunggaling } \\
\text { Karso }\end{array}$ & $\begin{array}{c}\text { Sidorejo } \\
4\end{array}$ & $\begin{array}{c}\text { Sumber } \\
\text { Anyar }\end{array}$ & $\begin{array}{l}\text { Tunas } \\
\text { Sari }\end{array}$ & Sri Rejeki & $\begin{array}{c}\text { Rukun } \\
\text { Maju } \\
\text { Sejahtera }\end{array}$ & $\begin{array}{c}\text { Ampel } \\
\text { Sari } \\
\text { Makmur } 2\end{array}$ \\
\hline $\begin{array}{l}\text { Regular } \\
\text { meeting } \\
\text { schedule }\end{array}$ & $\checkmark$ & $\sqrt{ }$ & $\sqrt{ }$ & $\checkmark$ & $\checkmark$ & v & $\checkmark$ & $\checkmark$ & $\checkmark$ \\
\hline $\begin{array}{l}\text { Dues or group } \\
\text { savings }\end{array}$ & - & - & - & - & - & - & - & - & $\checkmark$ \\
\hline $\begin{array}{l}\text { Access to } \\
\text { financial } \\
\text { institutions }\end{array}$ & - & - & - & - & - & - & $\checkmark$ & - & - \\
\hline $\begin{array}{l}\text { Facilitating } \\
\text { processing } \\
\text { activities }\end{array}$ & - & - & - & - & - & - & - & - & - \\
\hline $\begin{array}{l}\text { Collective } \\
\text { marketing of } \\
\text { produce }\end{array}$ & - & - & - & - & - & - & - & - & - \\
\hline $\begin{array}{l}\text { Production and } \\
\text { marketing of } \\
\text { processed coffee } \\
\text { products }\end{array}$ & - & - & - & - & - & - & $\checkmark$ & - & - \\
\hline $\begin{array}{l}\text { Facilitating } \\
\text { plantation } \\
\text { maintenance and/ } \\
\text { or helping each } \\
\text { other harvest } \\
\text { coffee }\end{array}$ & - & - & - & - & - & - & $\sqrt{ }$ & - & $\checkmark$ \\
\hline
\end{tabular}

farming and social activities is more dominant than that of women. Based on gender, respondents farmer groups are classified into two categories, namely groups consisting of men only and those consisting of women only. The number of men appointed group leader is higher than their female counterparts. As a result, group decision making is largely determined by the role of men. Moreover, it is usually easier for men to gain access to training compared to women. Despite their less favorable position in terms of access to resources, these female farmer groups participating in this research manage to prove that they are still able to seize opportunities and have access to the downstream coffee market. This condition shows that women play an important role in empowering groups through coffee-based business activities.

In general, the finding that the activity of facilitating farmer groups has not run is possibly because the role of group adminis- trators still has not brought about any significant impact. Group administrators have not facilitate their member farmers to improve their capacity and skills. This is evident from a limited exchange of information and knowledge owned by the administration related to farming and coffee processing to member farmers. In other words, the flow of information stops at the level of farmer group administrators and the information has not been passed on to member farmers. This may happen because training is given to group administrators only.

\section{Obstacles}

The implementation of collective processing in several survey locations run into problems. This happened because there were many farmers who sold their coffee based on a system called tebasan system and lack of water availability, especially for wet coffee processing, as well as the risk of theft. This 
condition was found in some sub-districts, namely Tutur, Purwodadi, and Puspo. Several farmer groups have got assistance in form of processing machines from related agencies. However, farmer groups did not use those machines optimally, even some farmer groups did not use them at all. In this case, farmer group administrators remained unable to excite their member farmers interest in carrying out collective processing. Assistance in form of processing machines came with a fairly large processing capacity thereby required enormous supply of raw materials. Therefore, group administrators needed to collect the harvest from its members to meet the processing capacity of those processing machines. The existing condition indicated the need for mentoring activities in an effort to encourage farmers to implement collective processing and marketing.

\section{CONCLUSIONS}

The coffee supply chain network in Pasuruan Regency is comprised of quite many links (marketing agencies) dominated by collectors. The highest profits from the marketing of Arabica coffee generated collectors are derived from selling coffee beans. The highest profits from the marketing of Robusta coffee generated collectors are derived from selling fresh coffee fruits. The roles and functions of farmer groups remain unable to improve the bargaining position of farmers and improve market access.

\section{ACKNOWLEDGEMENTS}

The author would like to express her gratitude to (i) the Plantation and Forestry Agency of Pasuruan Regency for providing funds to conduct this research; as well as to (ii) Dr. Ir. Retno Hulupi, SU. and Ir. Sugiyono for assisting in the survey activity.

\section{REFERENCES}

Anggraini, N.; A.I. Hasyim \& S. Situmorang (2013). Analisis efisiensi pemasaran ubi kayu di Provinsi Lampung. Jurnal Ilmu-Ilmu Agribisnis, 1, 80-86.

Barham, J. \& C. Chitemi (2009). Collective action initiatives to improve marketing performance: Lessons from farmer groups in Tanzania. Food Policy, 34, 53-59.

Cao, M. \& Q. Zhang (2011). Supply chain collaboration: impact on collaborative advantage and firm performance. Journal of Operations Management, 29, 163-180.

Cohen, N. \& T. Arieli (2011). Field research in conflict environments: methodological challenges and snowball sampling. Journal of Peace Research, 48, 423-435.

Doyle, P. (2009). Value-based Marketing: Marketing Strategies for Corporate Growth and Shareholder Value. John Wiley \& Sons, Inc. Hoboken, USA.

Gachena, D. \& S. Kebebew (2014). Analysis of coffee marketing cost and margins in South West, Ethiopia. Journal of Agricultural Research, 3, 165-173.

Godfrey, N. \& M.E.G. Agnes (2012). Analysis of round potato marketing in Tanzania: The case of Rungwe District, Tanzania. International Journal of Business and Social Science, 3, 86-96.

Handcock, M.S. \& K.J. Gile (2011). Comment: on the concept of snowball sampling. Sociological Methodology, 41, 367-371.

Hasibuan, A.M.; A. Wahyudi; D. Listyati; A. Aunillah; Ermiati \& M. Herman (2015). Peran organisasi petani dalam mengoptimalkan kinerja rantai pasok dan pembentukan nilai tambah kakao: Studi kasus di Kabupaten Kolaka, Sulawesi Tenggara. Jurnal Tanaman Industri dan Penyegar, 2, 1-12.

Hidayat, S.; Marimin; A. Suryani; Sukardi \& M. Yani (2012). Model identifikasi risiko dan strategi peningkatan nilai tambah pada rantai pasok kelapa sawit. Jurnal Teknik Industri, 14, 89-96. 
Hadiguna, R.A. \& D. Putra (2015). Dinamika Jaringan Rantai Pasok Biodiesel dari Minyak Goreng Bekas (Analisis, Pemodelan dan Kebijakan). Andalas University Press. Padang, Sumatera Barat, Indonesia.

Kendall, C.; L.R.F.S. Kerr; R.C. Gondim; G.L. Werneck; R.H.M. Macena; M.K. Pontes; L.G. Johnston; K. Sabin \& W. McFarland (2008). An empirical comparison of respondent-driven sampling, time location sampling, and snowball sampling for behavioral surveillance in men who have sex with men, Fortaleza, Brazil. AIDS and Behavior, 12, S97-S104.

Kipdiyah, S.; M. Hubeis \& B. Suharjo (2013). Strategi rantai pasok sayuran organik berbasis petani di Kecamatan Pangalengan, Kabupaten Bandung. Jurnal Manajemen Pengembangan Industri Kecil Menengah, 8, 99-114.

Lambert, D.M. \& M.C. Cooper (2000). Issues in supply chain management. Industrial Marketing Management, 29, 65-83.

Lokollo, E.M. (2012). Supply chain management (SCM) atau manajemen rantai pasok. p. 1-4. In: Bunga Rampai Rantai Pasok Komoditas Pertanian Indonesia. IPB Press. Bogor, Indonesia.

Lokollo (2012). Tinjauan kritis rantai pasok (SCM) komoditas pertanian Indonesia. p. 176-177. In: Bunga Rampai Rantai Pasok Komoditas Pertanian Indonesia. IPB Press. Bogor, Indonesia.

Mentzer, J.T.; W. DeWitt; J.S. Keebler; S. Min; N.W. Nix; C.D. Smith \& Z.G. Zacharia (2001). Defining supply chain management. Journal of Business Logistics, 22, 1-25.

Masrul, W. (2012). Pengembangan kelembagaan pertanian untuk peningkatan kapasitas petani terhadap pembangunan pertanian. MENARA Ilmu, III, 166-174.
Noy, C. (2008). Sampling knowledge: the hermeneutics of snowball sampling in qualitative research. International Journal of Social Research Methodology, 11, 327-344.

Rahman, D.; Elwamendri \& Y. Damayanti (2014). Analisis tataniaga pinang (Areca catechuL.) pada pasar produsen di Kecamatan Muara Sabak Timur Kabupaten Tanjung Jabung Timur. Sosio Ekonomika Bisnis, $17,1-11$.

Said, A.I. (2006). Tantangan penerapan SCM di perusahaan. p. 2-17. In: Produktivitas \& Efisiensi dengan Supply Chain Management. (A.I. Said; B.A. Soedjarwo; C.L. Benarto; H. Lembito; R. Satria \& S. Winarto, Eds.). Penerbit PPM. Jakarta, Indonesia.

Tollens, E.F. (2006). Market information systems in sub-Sahara Africa Challenges and Opportunities. The International Association of Agricultural Economists Conference. Gold Coast, Australia.

Widiastuti, N. \& M. Harisudin (2013). Saluran dan marjin pemasaran jagung di Kabupaten Grobogan. SEPA, 9, 231-240.

Widyarto, A. (2012). Peran supply chain management dalam sistem produksi dan operasi perusahaan. BENEFIT Jurnal Manajemen dan Bisnis, 16, 91-98.

Winarto, S. (2006). Merancang end-to-end supply chain management. p. 74-89. In: Produktivitas \& Efisiensi dengan Supply Chain Management. (A.I. Said; B.A. Soedjarwo; C.L. Benarto; H. Lembito; R. Satria \& S. Winarto, Eds.). Penerbit PPM. Jakarta, Indonesia.

Zunaidah, A.D.; B. Setiawan \& R. Anindita (2015). Analisis integrasi pasar apel (Kasus di Desa Sumbergondo, Kota Batu, Jawa Timur). Habitat, 26, 183-194.

$$
* * 0 * *
$$

